Q.630.7

I $\ell$ 6C

no. 1306 


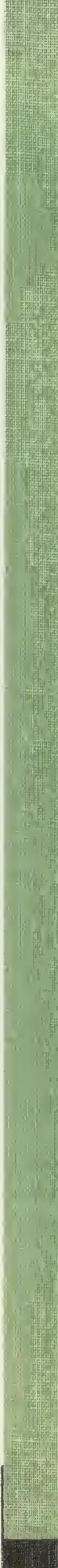


UNIVERSIIY ,

ILLINOIS LIB

T) URBANA-CHAMF AGRICIII TURE 
Digitized by the Internet Archive in 2011 with funding from University of Illinois Urbana-Champaign 


\section{Weed Control Systems for Lo-Till and No-Till}

c University of Illinois at Urbana-Champaign 306 College of Agriculture Cooperative Extension Service Circular 1306

AGRICULTURE LIBRARY

JAAN 30 1991 
Prepared by Ellery L. Knake, professor of weed science research and Extension, Department of Agronomy, College of Agriculture, University of Illinois at Urbana-Champaign.

Editor: Anita Povich

Designer: Joan R. Zagorski

$\begin{array}{ll}\text { Helping You } \\ \text { Illinois } & \begin{array}{l}\text { Put Knowledge to Work } \\ \text { Cooperative }\end{array} \\ \begin{array}{l}\text { University of Illinois } \\ \text { at Urbana-Champaign } \\ \text { Extension }\end{array} & \begin{array}{l}\text { College of Agriculture } \\ \text { Service }\end{array}\end{array}$

Urbana, Illinois

October, 1990

Issued in furtherance of Cooperative Extension Work, Acts of May 8 and June 30, 1914, in cooperation with the U.S. Department of Agriculture, DONALD L. UCHTMANN, Director, Cooperative Extension Service, University of Illinois at Urbana-Champaign.

The Cooperative Extension Service provides equal opportunities in programs and employment. 


\section{Weed Control Systems for Lo-Till and No-Till}

As

$s$ farmers become more interested in resource conservation, many are deciding to reduce tillage to keep some crop residue on top of the soil. In addition to conserving soil, lo-till and no-till systems can help conserve fossil fuel, trips over the field, and equipment expense. (In this publication, lo-till refers to the various methods of reduced tillage other than no-till.) Some farmers are now using a chisel plow, disk, or field cultivator in place of a moldboard plow. Others are opting for tillage rotation, with little or no tillage some years and more tillage perhaps every second year.

Both university research and farmer experience suggest that no-till can be quite successful. However, it can also be a significant challenge. Depending on the situation, yields may be less than, equal to, or greater than yields where some tillage is used.

Many factors affect the type of tillage system used, including the soil, the cropping system, the farm's conservation plan, the type of equipment available, and personal preference. The purpose of this publication is to suggest weed control methods for various tillage systems rather than to recommend a particular tillage system. Because some herbicides will be discontinued and new herbicides will become available to improve weed control in conservation tillage systems, weed control recommendations presented will be somewhat general in nature. For more specific weed control information, refer to current weed control guides and herbicide labels.

As tillage is reduced, some weeds, such as velvetleaf, may become less of a problem. However, other weeds, such as fall panicum, marestail, hemp dogbane, and common milkweed, may proliferate. (Marestail is officially known as horseweed, Conyza canadensis, but referred to as marestail in this publication.)

Although it is a common belief that no-till and lotill require more herbicide and increased costs, this is not necessarily true. University weed scientists have discovered techniques for avoiding increased herbicide expenditures. Furthermore, herbicide use may even be decreased by taking advantage of certain cover crops or mulches.

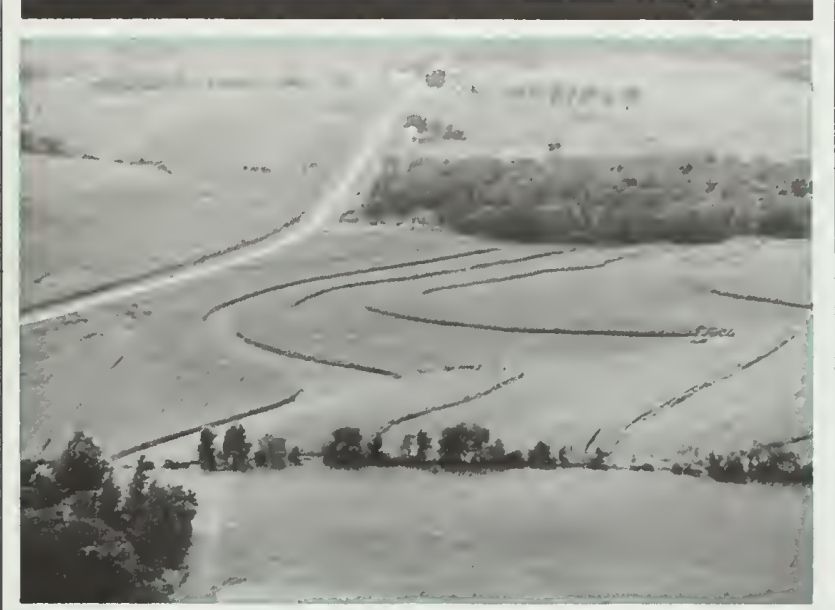

Contouring and terracing have long been advocated in some areas to help reduce soil erosion.

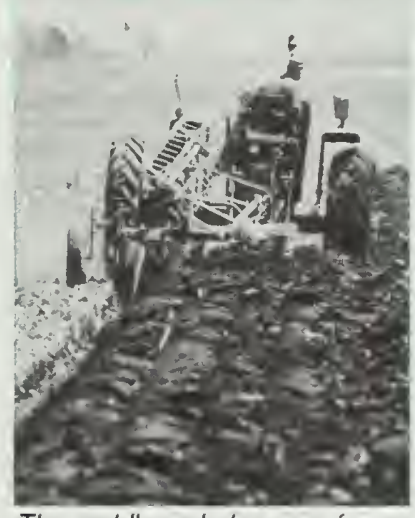

The moldboard plow was formerly used on a high percentage of the land in Illinois.

In recent years, the chisel plow has often replaced the moldboard plow.
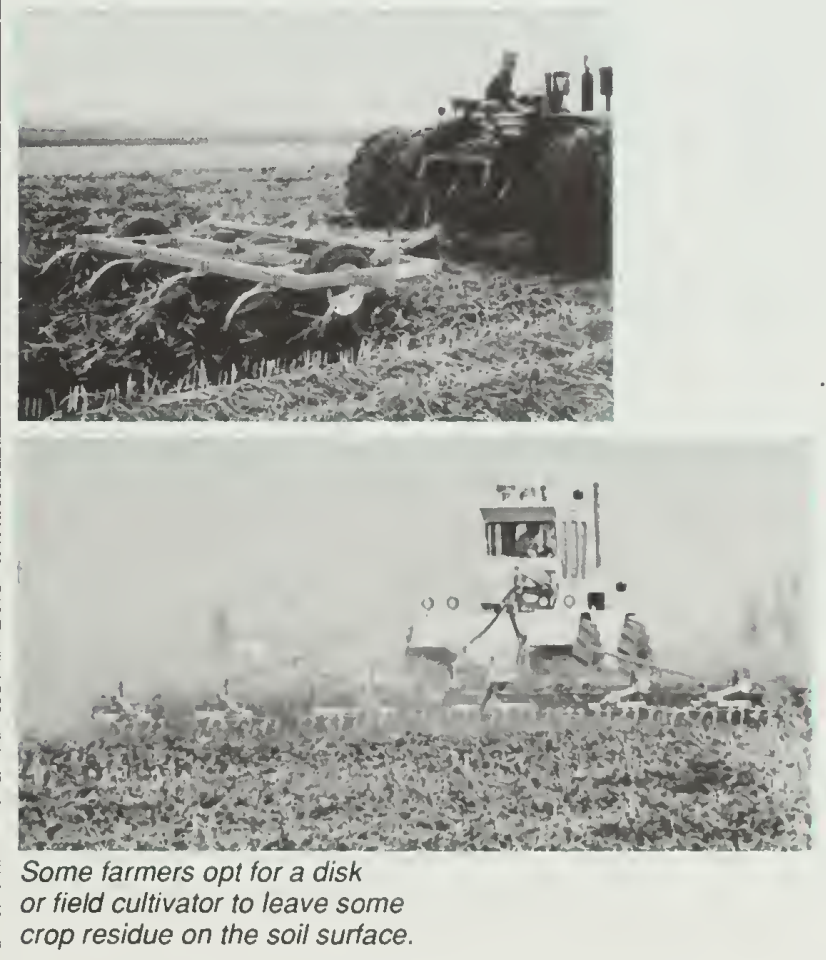


\section{Corn Following Soybeans}

In Illinois there are nearly as many acres of soybeans as of corn, and many farmers grow the two in sequence. Because soybeans usually leave the soil in good physical condition, corn can often be planted very easily after soybeans without any tillage. If you prefer to incorporate herbicides, leave soybean stubble over winter and apply the herbicide to the stubble in the spring while incorporating at the same time. Although some may argue that soybeans do not leave much crop residue, leaving soybean stubble over winter and using little or no tillage in the spring can constitute a giant step toward meeting resource conservation goals.

Leaving soybean stubble over winter can allow considerable convenience for application of agricultural chemicals in the spring.

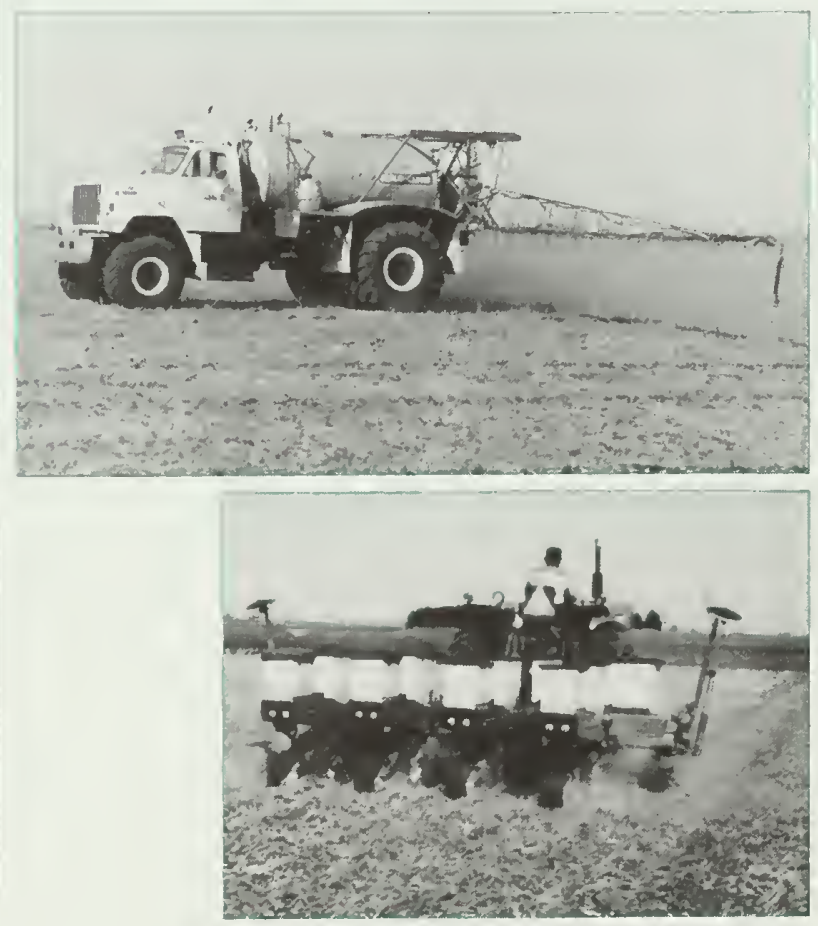

Soybeans often leave the soil rather mellow to allow planting corn directly in the soybean stubble with no tillage.
University research trials with corn no-till after soybeans have produced excellent yields with good weed control from commonly used herbicides-and generally without having to increase herbicide rates or costs (Tables 1 and 2). Although good results have been achieved without tillage or row cultivation, common sense should prevail if the situation warrants a little extra herbicide or some cultivation.

With early planting preceded by preplant herbicide application, there may be few, if any, weeds present when the herbicide is applied. If there are weeds present, however, they can be killed during incorporation. For no-till, herbicides such as atrazine and Bladex, with both postemergence and preemergence activity, can also easily control

Table 1. Early Preplant Herbicide Treatments for Corn Planted in Soybean Stubble

\begin{tabular}{|c|c|c|c|}
\hline Herbicide & $\frac{\text { Rate }}{(\mathrm{lb} / \mathrm{A})}$ & $\frac{\text { Weed control }}{\text { (percent) }}$ & $\frac{\text { Yield }}{(\mathrm{bu} / \mathrm{A})}$ \\
\hline Atrazine & 3 & 94 & 208 \\
\hline Bladex & 4 & 94 & 209 \\
\hline Atrazine & & & \\
\hline $\begin{array}{l}+ \text { Bladex } \\
\text { Atrazine }\end{array}$ & $1.5+3$ & 96 & 212 \\
\hline $\begin{array}{l}+ \text { Dual } \\
\text { Atrazine }\end{array}$ & $2+2$ & 96 & 206 \\
\hline $\begin{array}{l}\text { + Bladex + 2,4-D } \\
\text { Atrazine }\end{array}$ & $2+2+0.5$ & 95 & 209 \\
\hline + Bladex + Banvel & $2+2+0.25$ & 95 & 208 \\
\hline Mean & & 95 & 209 \\
\hline
\end{tabular}

Table 2. Early Preplant Herbicide Treatments for Corn After Soybeans with No-Till or One- or Two-Pass Incorporation

\begin{tabular}{|c|c|c|c|c|}
\hline \multirow[b]{2}{*}{ Herbicide } & \multirow{2}{*}{$\frac{\text { Rate }}{(\mathrm{lb} / \mathrm{A})}$} & \multicolumn{2}{|c|}{ Weed control } & \multirow{2}{*}{$\frac{\text { Yield }}{\text { (bu/A) }}$} \\
\hline & & $\begin{array}{l}\text { Giant } \\
\text { foxtail }\end{array}$ & $\begin{array}{l}\text { Velvet- } \\
\text { leaf }\end{array}$ & \\
\hline & \multicolumn{4}{|c|}{ - - percent... } \\
\hline Atrazine & 3 & 100 & 90 & 175 \\
\hline Bladex & 4 & 100 & 100 & 177 \\
\hline Atrazine + Bladex & $1.5+3$ & 100 & 100 & 183 \\
\hline Atrazine + Dual & $2+2$ & 100 & 92 & 174 \\
\hline $\begin{array}{l}\text { Atrazine + Lasso } \\
\text { "Eradicane }\end{array}$ & $2+2.5$ & 100 & 97 & 183 \\
\hline $\begin{array}{l}\text { + Atrazine (1 pass) } \\
\text { Eradicane }\end{array}$ & $4+2$ & 100 & 97 & 183 \\
\hline + Atrazine (2 passes) & $4+2$ & 100 & 100 & 177 \\
\hline "Incorporated & Mean & 100 & 97 & 179 \\
\hline
\end{tabular}
all tables. 
some early weeds, such as smartweed. Banvel and 2,4-D are other relatively low-cost options that can help control perennial as well as annual broadleaf weeds. Gramoxone and Roundup can help against both broadleaf and grass weeds. The type of herbicide chosen and the application rate will depend on the type of vegetation present. The best time to control some perennials, such as hemp dogbane and quackgrass, is in the fall so that the herbicide can be translocated to the roots and rhizomes when energy reserves are moving downward. When the crop has not yet been

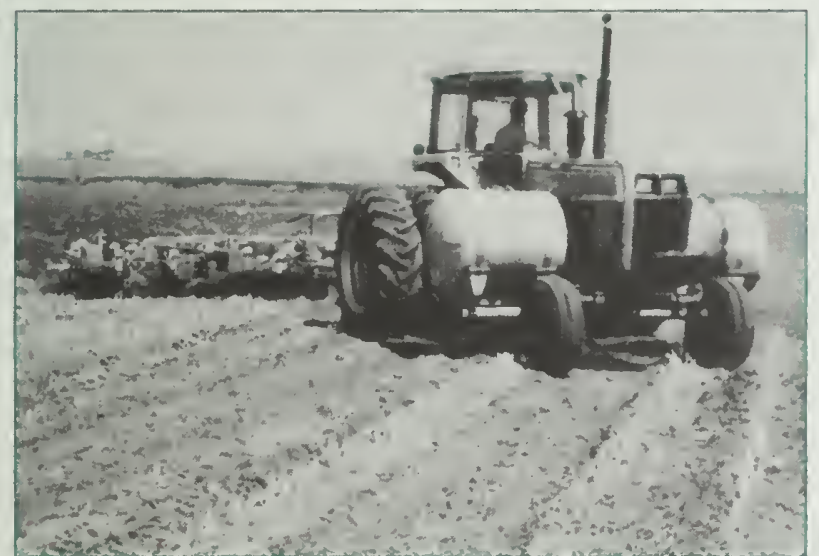

For those who prefer to incorporate herbicides, the application may be made directly to the soybean stubble with incorporation performed at the same time.

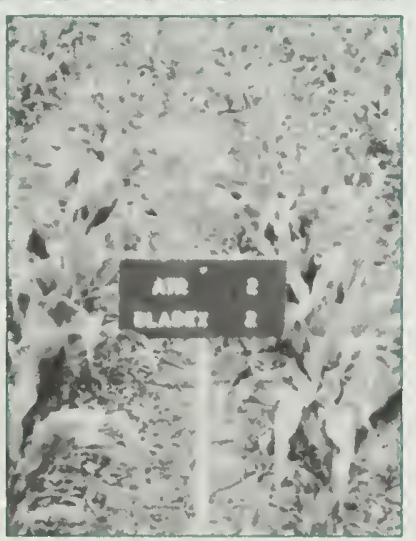

Applying herbicides to soybean stubble early, when there is little or no weed growth present. may give adequate weed control without increasing herbicide rates or costs. A spray-plant-harvest program with no tillage or cultivation can allow significant savings. planted, the addition of adjuvants, such as crop oil concentrate and fertilizer solution, can enhance postemergence activity when used within label guidelines.

Herbicides such as Lasso and Dual can enhance grass control. They can be applied to the surface or incorporated. Herbicides such as Sutan+ and Eradicane have generally performed well when applied directly to soybean stubble and incorporated.

Sometimes additional help is needed after crop emergence. Several postemergence herbicides, such as atrazine, Bladex, 2,4-D, Banvel, Marksman, Laddok, Basagran, Buctril, and Buctril plus atrazine, are available for these situations, with the triazines providing some control of both small grasses and broadleaf weeds. Accent for corn has performed very well on grass weeds such as shattercane, johnsongrass, quackgrass, and fall panicum, as well as on foxtail. It is also effective on some broadleaf weeds. Although Beacon is not as effective as Accent on some annual grass weeds, such as giant foxtail, it provides good control of shattercane and johnsongrass, and is more effective than Accent on some broadleaf weeds, such as cocklebur. Accent may offer new opportunities for lo-till and no-till corn.

\section{Corn Following Corn}

Lo-till or no-till can also be successful with continuous corn if managed appropriately. With continuous no-till corn, a mulch of corn crop residue can gradually build up to improve moisture retention and help control some weeds. However, other weeds, such as fall panicum, may intensify. Fall panicum's small seeds can filter through the crop residue to the moist microclimate below where they germinate readily.

Although control of fall panicum has been somewhat challenging in continuous no-till corn, it can be controlled. While the main concern with giant foxtail is early growth, panicum tends to germinate both early and in midseason. Herbicides such as Lasso and Dual can help control the early flush of panicum. The microtech formulation of Lasso may have a slight advantage over the emulsifiable concentrate formulation. 
Atrazine is weak on panicum, but simazine or Bladex can be helpful. Prowl applied postemergence to the corn can provide residual activity to extend control, or Treflan can be incorporated as corn is cultivated. A midseason application of an acetanilide herbicide, such as Dual, can extend control as well.

If perennial weeds intensify with reduced tillage, you may need to apply a translocated herbicide, such as 2,4-D, Banvel, or Roundup. Basagran or Laddok applied postemergence can help control some perennials, such as Canada thistle and nutsedge.

Although continuous corn may be justified in some areas, a cropping sequence or rotation accompanied by a tillage rotation can generally provide more opportunities to control specific weeds. Grasses such as fall panicum, wirestem muhly, johnsongrass, and shattercane have been much easier to control with some herbicides for soybeans. However, Accent and Beacon offer new help for some of these weeds in corn. Avoiding a monoculture and using a variety of herbicides or a herbicide rotation can also help prevent the development of herbicide-resistant weeds.

\section{Soybeans Following Corn}

On relatively level land that is not subject to much soil erosion, a chisel plow and/or disk or field cultivator are often used after corn in preparation for soybeans. Such tillage allows the use of some incorporated herbicides, such as trifluralin, which have been quite effective, economical, and popular for soybeans.

Improved planting equipment and an increasing arsenal of herbicides for soybeans are enhancing the chances of success with no-till soybeans. You should consider early burndown of grass and broadleaf weeds, as well as residual control with preemergence herbicides. Postemergence treatments may also be adequate.

Roundup or Gramoxone can burn down both grass and broadleaf weeds. For burndown of grass, Roundup, Gramoxone, or postemergence grass killers such as Poast, Fusilade, and Assure, can be effective. Check labels for approved uses. If applied early enough, 2,4-D is a possibility for

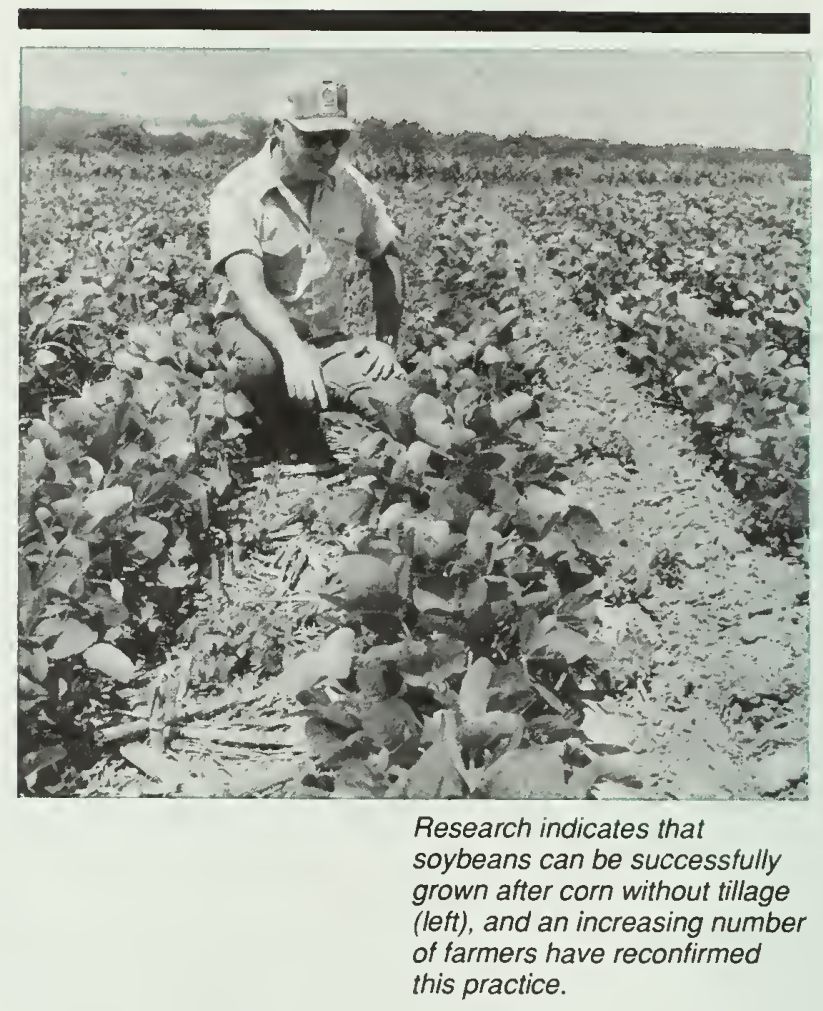

control of broadleaf weeds. Some of these herbicides can also be used together to provide burndown of both grass and broadleaves. For example, you might combine an early application of 2,4-D for control of broadleaf weeds with a herbicide such as Poast for early burndown of grass weeds. Later, you might apply herbicides such as Basagran and Blazer, and then one such as Poast.

Lorox and Lorox Plus can have postemergence as well as preemergence activity, as can Sencor and Lexone. One of the ingredients in Preview, Canopy, and Lorox Plus is the same active ingredient found in Classic, which is used postemergence. A higher rate of this active ingredient (chlorimuron ethyl) in Preview, Canopy, and Lorox Plus provides significant burndown as well as residual control.

In research trials, Preview and Canopy have performed well for both burndown and residual activity. Control of marestail (often a significant problem in no-till) has been quite impressive with Preview and Canopy. One possibility would be to apply Preview or Canopy for burndown and residual control. Then if more help is needed for grass control, apply a postemergence herbicide such as Assure.

Herbicides such as Lasso, Dual, and Prowl can provide residual preemergence activity to control grass. A combination premix such as Bronco, which contains the active ingredients of both Roundup and Lasso, can give burndown of broadleaf and grass weeds as well as residual control of 
grass. A preemergence or postemergence herbicide for broadleaf weeds might be used in conjunction with Bronco.

There has been a significant increase in the number of postemergence herbicides for soybeans for both grass and broadleaf control. Although the activity of postemergence herbicides is generally greater during warmer weather, some of these compounds can be applied for early burndown, with additional postemergence treatments later for more control.

While the above information may not provide a "cookbook" approach for lo-till or no-till soybeans, it will hopefully stimulate thinking as some new possibilities develop to further enhance the chances of success.

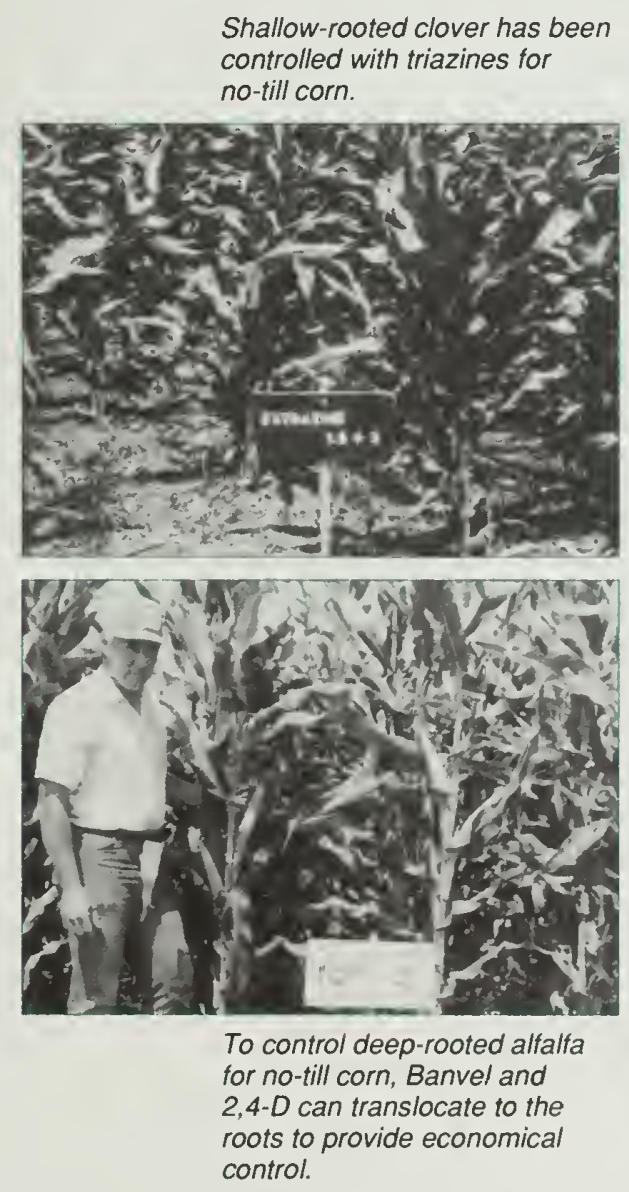

\section{No-Till Corn in Sod}

Small-seeded legumes and grasses may be used for pasture, hay, or set-aside. When rotating the land back to corn there is an opportunity for notill. Although no-till corn in sod can work well, it is not always as successful as desired. Some farmers would like to harvest a crop of hay before no-tilling corn in sod. However, the removal of moisture by the forage crop may create a moisture shortage for the corn, especially in a dry year. Therefore, it is sometimes best to kill the sod early and not try to harvest the hay. If you do harvest the hay, allow sufficient regrowth for the herbicide to be effective. In a wet spring, no-till planting in sod may allow earlier field operations.

The feasibility and cost of grass control vary considerably. Bluegrass can be controlled easily with atrazine, and timothy is also relatively easy to control. A combination of atrazine and Gramoxone has been effective on tall fescue. Fall treatments that include atrazine may help on bromegrass. Orchardgrass may require 2 quarts or more of Roundup if treated in the spring. Advanced planning for fall treatment of perennial grasses and some legumes can help ensure effective control and lower costs.

Where there is a pure stand of clover or alfalfa, control is usually easier and less expensive than where grass is also present. For shallow-rooted clover such as red clover, the triazines can give good control if moisture is adequate (Tables 3 and 4). A combination of approximately $11 / 2$ to 2 pounds each of atrazine and Bladex has worked well. Premix combinations such as Extrazine II are also effective. Under relatively dry conditions, activity may be a little slow. In these cases, a modest rate of Banvel can help, or, for some clover, 2,4-D will be adequate. Sweet clover is quite sensitive to 2,4-D while ladino is less so. Red clover can be controlled by either 2,4-D or Banvel, but a combination is often preferred for broader spectrum control of weeds that may also be present. Since mammoth red clover seed is relatively inexpensive, it may be worth considering for set-aside. 
Table 3. Corn with Tillage Versus Corn No-Till in Clover Sod

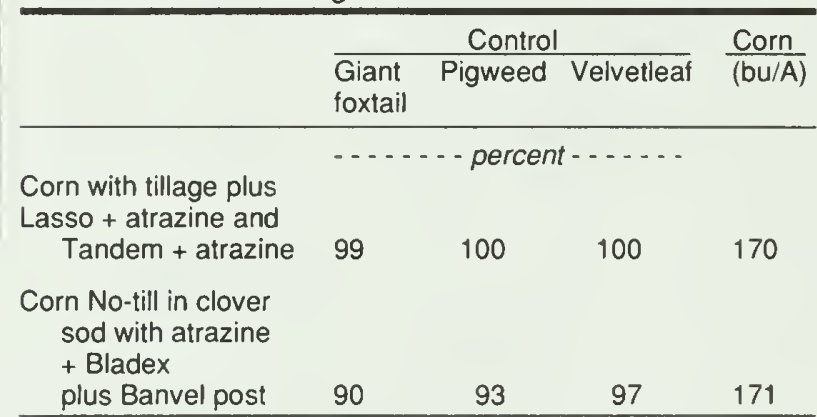

Table 4. Corn in Clover Sod

\begin{tabular}{|c|c|c|c|c|}
\hline Herbicide & $\frac{\text { Rate }}{(\mid \mathrm{b} / \mathrm{A})}$ & \multicolumn{2}{|c|}{ Control } & $\frac{\text { Corn }}{(\mathrm{bu} / \mathrm{A})}$ \\
\hline & \multicolumn{4}{|c|}{ - - percent - . - } \\
\hline $\begin{array}{l}\text { "Atrazine + } \\
\text { Bladex }\end{array}$ & $1.5+3$ & 97 & 100 & 153 \\
\hline $\begin{array}{l}\text { "Atrazine + } \\
\text { Lasso }\end{array}$ & $3+2.5$ & 95 & 100 & 149 \\
\hline $\begin{array}{l}\text { *Atrazine + } \\
\text { Dual }\end{array}$ & $3+2$ & 95 & 100 & 149 \\
\hline $\begin{array}{c}\text { Atrazine }+ \\
\text { Prowl }\end{array}$ & $3+1$ & 100 & 100 & 149 \\
\hline $\begin{array}{l}\text { *Atrazine + } \\
\quad \text { Bladex + Dual }\end{array}$ & $1.5+1.5+1.5$ & 100 & 100 & 149 \\
\hline $\begin{array}{l}\text { *Atrazine + } \\
\text { Bladex + Dual }\end{array}$ & $1.5+1.5+1.5$ & 87 & 30 & 144 \\
\hline
\end{tabular}

Table 5. Corn in Alfalfa Sod

\begin{tabular}{|c|c|c|c|c|c|}
\hline \multirow{2}{*}{ Herbicide } & $\frac{\text { Rate }}{(\mathrm{lb} / \mathrm{A})}$ & \multicolumn{3}{|c|}{ Control } & $\frac{\text { Corn }}{(\mathrm{bu} / \mathrm{A})}$ \\
\hline & \multicolumn{5}{|c|}{. . . - percent - . . . - } \\
\hline$* 2,4-D+$ Dual & & & & & \\
\hline+ atrazine & $1+2+2$ & 88 & 100 & 100 & 154 \\
\hline${ }^{*} 2,4-D+$ Banvel & $0.5+0.5$ & 96 & 100 & 100 & 148 \\
\hline $\begin{array}{c}{ }^{*} \text { Banvel + Dual pre } \\
+ \text { Banvel post }\end{array}$ & $\begin{array}{l}0.25+2 \\
0.5\end{array}$ & 99 & 100 & 100 & 142 \\
\hline $\begin{array}{c}{ }^{\star} \text { Banvel + Dual pre } \\
\text { + Banvel post }\end{array}$ & $\begin{array}{l}0.25+2 \\
0.5\end{array}$ & 100 & 100 & 100 & 130 \\
\hline
\end{tabular}

Pure stands of alfalfa can also be controlled effectively and economically for no-till corn (Table 5). However, translocated herbicides are needed for this deep-rooted legume. Usually about 2 pints of 2,4-D (3.8 $\mathrm{lb} / \mathrm{gal}$ a.e.) or about a half pint of Banvel plus 1 pint of 2,4-D ester (3.8 lb/gal a.e.) can be effective, if not applied too early. Activity generally increases toward bloom stage. Although Roundup is quite effective on many perennials, good control of alfalfa with Roundup should not be expected with spring treatments. Banvel is more effective than 2,4-D on some weeds such as smartweed. However, dandelion can be a significant problem in no-till, and 2,4-D is more effective on it than is Banvel. Therefore, a 2,4-D-plusBanvel combination can significantly broaden the spectrum of control and reduce cost.

\section{No-Till Soybeans in Sod}

There is some advantage to planting corn rather than soybeans in legume sod to take advantage of the nitrogen, although soybeans can be successfully grown no-till after clover or alfalfa (Table 6). The key is to plan ahead and use 2,4-D or Banvel in the fall within label guidelines. Banvel should not be used in the spring ahead of soybeans because of possible injury to soybeans. The use of 2,4-D may be feasible if applied sufficiently early in the spring within label guidelines. Soybeans should not be planted in untreated clover or alfalfa because selective postemergence treatments for killing these legumes in soybeans have not been developed. However, if a little biennial sweet clover survives in soybeans, it may die naturally.

Research indicates that although no-till soybeans in grass sod is possible, it generally is not as feasible as some other no-till options (Table 7). Sencor or Lexone plus Gramoxone may give fair control of some grass species. Roundup can be effective if rates are adequate and fall treatments are given preference. Some postemergence grass killers for soybeans may be effective, but susceptibility of perennial grasses varies with the different herbicides, and the rates needed may be costly. 


\section{Small-Grain Cover Crops}

In preparation for no-till corn or soybeans, it may be necessary to kill wheat or rye that was seeded to reduce erosion or to finish killing a wheat stand that has been significantly thinned by ice, lack of snow cover, or standing water. Wheat is generally easier to kill than rye. Although triazines alone may sometimes be considered for corn, adding modest rates of Gramoxone or Roundup can be helpful (Table 8). For soybeans, Gramoxone or

Table 6. Soybeans in Clover and Alfalfa Sod

\begin{tabular}{|c|c|c|c|c|c|c|c|}
\hline \multirow[b]{2}{*}{ Herbicide } & \multirow[b]{2}{*}{$\begin{array}{l}\text { Rate } \\
\mathrm{Ib} / \mathrm{A}\end{array}$} & \multicolumn{4}{|c|}{ Control } & \multicolumn{2}{|c|}{ Soybeans (bu/A) } \\
\hline & & Alfalfa & $\begin{array}{l}\text { Red } \\
\text { Clover }\end{array}$ & Foxtail & $\begin{array}{l}\text { Velvet- } \\
\text { leaf }\end{array}$ & Alfalfa & Clover \\
\hline \multicolumn{8}{|l|}{ Fall: } \\
\hline Banvel & 0.5 & 80 & 100 & 100 & 100 & 47 & 53 \\
\hline $2,4-D$ & 1 & 100 & 100 & 100 & 100 & 49 & 56 \\
\hline Banvel + 2,4-D & $0.5+0.5$ & 100 & 100 & 100 & 100 & 47 & 52 \\
\hline Roundup & 2 & 98 & 100 & 100 & 100 & 51 & 56 \\
\hline \multicolumn{8}{|l|}{ Spring: } \\
\hline $2,4-D$ & 1 & 73 & 83 & 100 & 100 & 38 & 52 \\
\hline Roundup & 2 & 47 & 47 & 100 & 100 & 31 & 39 \\
\hline
\end{tabular}

Table 7. Control of Established Vegetation for No-Till Corn

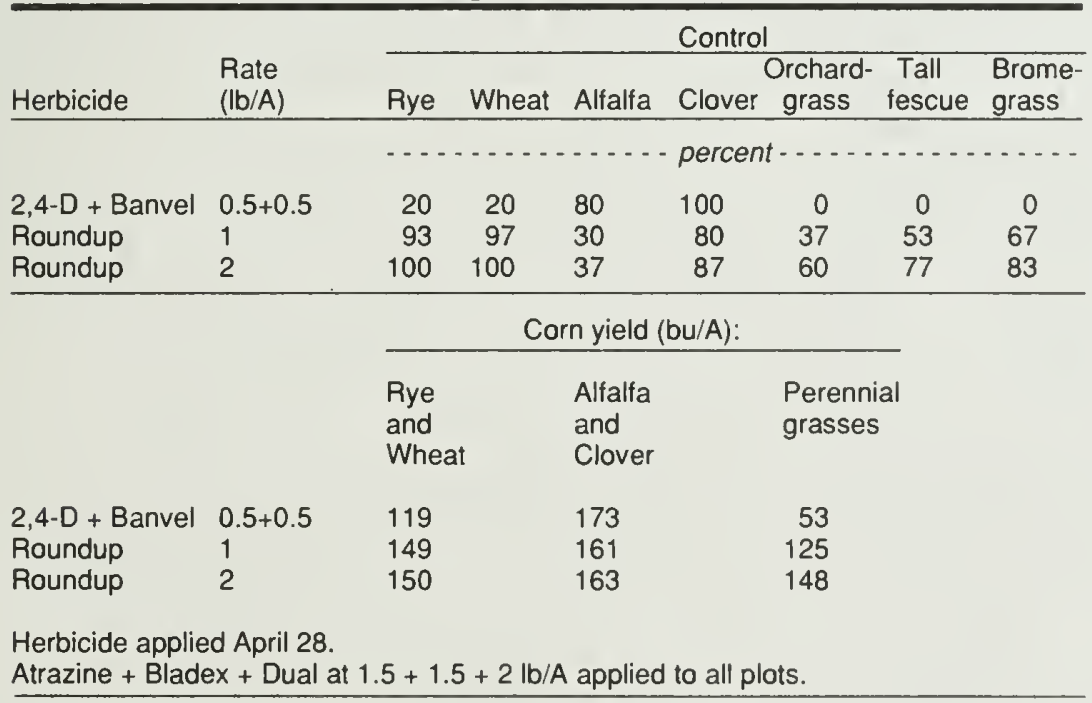

Roundup plus preemergence residual herbicides can be effective. Of the postemergence grass killers, Fusilade and Assure have been effective in research trials for killing wheat and have given some control of rye (Table 9).

Where spring oats have been seeded for setaside and allowed to reseed to produce a dense mulch for late summer, fall, and winter, the oats will be killed by winter weather. Corn or soybeans can be no-tilled into the mulch in the spring, and preemergence and postemergence herbicides can be used as needed.

Small-grain, legume, or grass cover crops can reduce soil erosion and allow earlier field operations in a wet year. However, in a dry year they may have a detrimental effect on corn or soybeans. Therefore, they should be killed in fall or early spring if moisture depletion is to be avoided.

\section{Double-Crop Soybeans After Wheat}

In the southern portion of Illinois, planting soybeans with little or no tillage after wheat harvest in late June or early July has been relatively popular. Usually a burndown herbicide, such as Gramoxone or Roundup, plus one or more preemergence herbicides for residual control is adequate. In some situations, postemergence herbicides alone may be adequate for soybeans. If volunteer wheat poses a problem, a herbicide such as Assure, Fusilade, or Poast can be helpful.

Occasionally, sorghum may be double-cropped after wheat. Again, a reminder that both burndown and residual activity should be considered. 


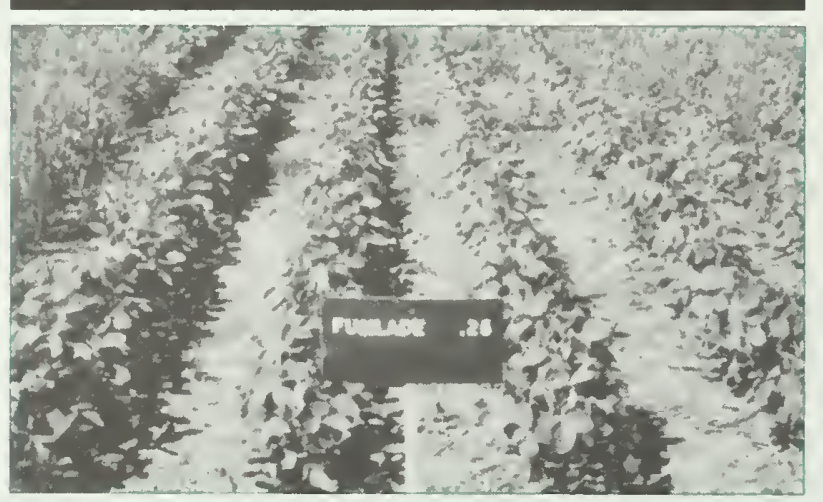

In research trials, Roundup, Gramoxone, Fusilade, and Assure have given control of wheat which has been used for a cover crop ahead of no-till soybeans.

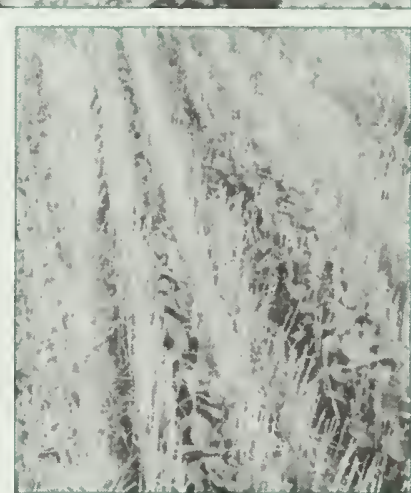

Doublecropping soybeans after wheat has been a popular practice in the wheat-producing areas of southern Illinois.

Some farmers have had good success using a ridge-till system.
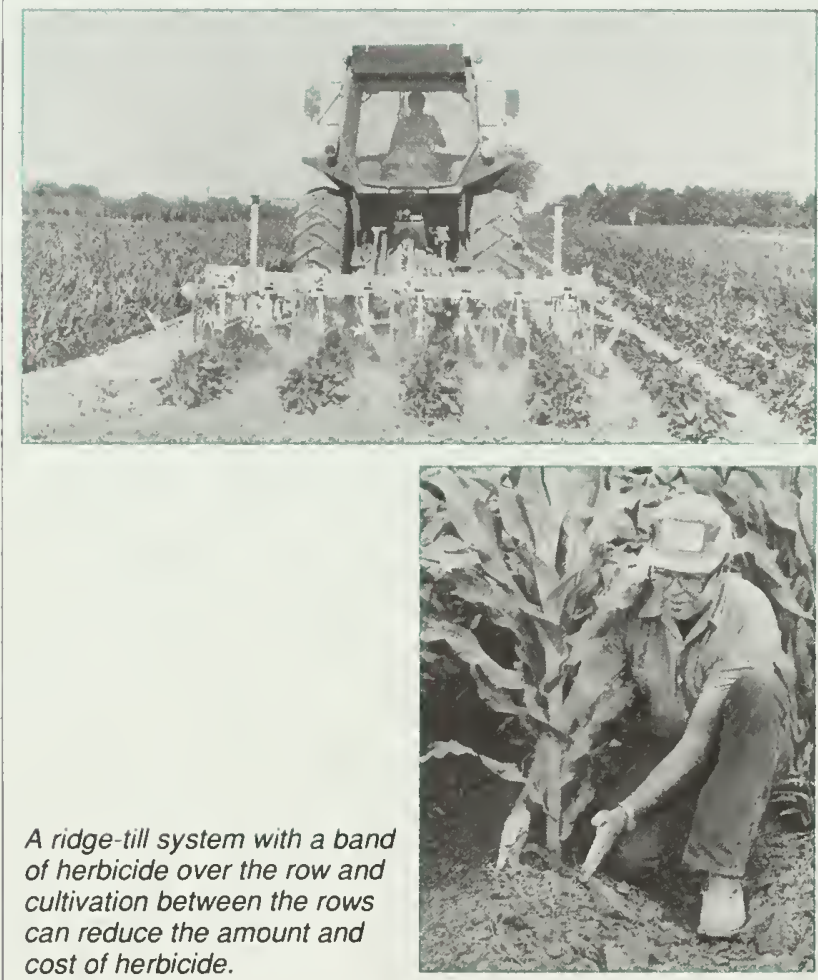

\section{Ridge-Till}

Ridge-till, which has been successfully used by some Illinois farmers, presents opportunities for banding herbicides over the row and cultivating between the rows. Although ridge-till may not completely preclude the use of incorporated herbicides, greater reliance is generally placed on surface-applied preemergence herbicides and selective postemergence treatments. Herbicide treatments have been quite successful for ridge-till, and many of the principles and considerations for other tillage systems apply to ridge-till as well.

\section{Is Cultivation Necessary?}

During the first forty years of this century most farmers "check planted" corn. That is, they used a wire with "knots" evenly spaced to trip the planter so the hills of corn would be lined up in two directions to allow cultivation both ways. Many farmers cultivated three or four times.

There has been some controversy over the years about the possible benefits of cultivation other than for weed control. Several decades ago, before the advent of the herbicide era, studies were conducted in Illinois to determine if there was any benefit from cultivation other than for controlling weeds. Some plots were cultivated and others were simply scraped with a hoe to remove weeds. The general conclusion was that the main purpose of cultivation was for weed control.

With the advent of new herbicides in the late 1950 s, farmers started questioning the need to cultivate when they could achieve good weed control with herbicides. In the early 1960 s, a threeyear study was conducted on seven different soils distributed over the state. Two tillage systems were used. All plots were moldboard plowed, but some were disked only once while others were disked three times. Some plots had no herbicide but were cultivated, some had herbicide only, and others had both herbicide and cultivation. All plots were kept completely weed free. Cultivated plots were touched up with a hand hoe. On the "herbicide only" plots, a hand flamer was used instead of a hoe to ensure that the soil was not disturbed. 
Table 8. Control of Wheat and Rye Cover Crops for Corn

\begin{tabular}{|c|c|c|c|}
\hline \multirow[b]{2}{*}{ Herbicide } & \multirow{2}{*}{$\frac{\text { Rate }}{|\mathrm{b} / \mathrm{A}|}$} & \multicolumn{2}{|c|}{ Control } \\
\hline & & Wheat & Rye \\
\hline & & \multicolumn{2}{|c|}{ - - - percent -... } \\
\hline $\begin{array}{l}\text { Atrazine } \\
\text { Atrazine }\end{array}$ & $\begin{array}{l}1.5 \\
3.0\end{array}$ & $\begin{array}{l}30 \\
65\end{array}$ & $\begin{array}{l}43 \\
69\end{array}$ \\
\hline $\begin{array}{l}\text { Bladex } \\
\text { Bladex }\end{array}$ & $\begin{array}{l}2.0 \\
4.0\end{array}$ & $\begin{array}{l}18 \\
35\end{array}$ & $\begin{array}{l}23 \\
54\end{array}$ \\
\hline Atrazine + Bladex & $2+2$ & 65 & 80 \\
\hline Atrazine + Bladex & $1.5+3$ & 65 & 79 \\
\hline Paraquat + Atrazine & $0.5+2$ & 95 & 94 \\
\hline Paraquat + Bladex & $0.5+3$ & 86 & 86 \\
\hline Roundup + Atrazine & $1.6+2$ & 100 & 94 \\
\hline $\begin{array}{l}\text { Roundup + Bladex + } \\
\text { Atrazine }\end{array}$ & $1+3+1$ & 96 & 91 \\
\hline
\end{tabular}

Table 9. Control of Wheat and Rye Cover Crops for Soybeans

\begin{tabular}{|c|c|c|c|}
\hline \multirow[b]{2}{*}{ Herbicide } & \multirow{2}{*}{$\frac{\text { Rate }}{(\mathrm{lb} / \mathrm{A})}$} & \multicolumn{2}{|c|}{ Control } \\
\hline & & Wheat & Rye \\
\hline & & \multicolumn{2}{|c|}{ - - - percent...} \\
\hline Roundup & 0.50 & 84 & 50 \\
\hline Roundup & 0.75 & 89 & 63 \\
\hline Roundup & 1.00 & 99 & 89 \\
\hline Paraquat & 0.25 & 65 & 70 \\
\hline Paraquat & 0.50 & 83 & 80 \\
\hline Fusilade & 0.25 & 94 & 53 \\
\hline Assure & 0.10 & 95 & 60 \\
\hline Verdict & 0.12 & 91 & 53 \\
\hline Poast & 0.25 & 40 & 31 \\
\hline Option & 0.15 & 10 & 10 \\
\hline Select & 0.125 & 48 & 28 \\
\hline
\end{tabular}

Again, the general conclusion was that the main reason for cultivation was to control weeds. For soils in good tilth, there was generally no benefit from cultivation other than for weed control, although cultivation did slightly enhance yields for soils with low organic matter that had been overworked by disking and had some crusting.

Some people question whether the data are still valid. It is true that cultural practices have changed. Plant populations are higher, rows narrower, and yields higher. These factors have probably resulted in more organic matter being added to the soil and perhaps improving soil tilth. Although large equipment may have caused compaction in some fields, the majority of Illinois soils are in relatively good physical condition and tilth. Although more recent studies may not be as detailed, many current observations still suggest that the main reason for cultivation is to control weeds. Herbicides generally provide good weed control, but if some weeds remain, rotary hoeing and one or two cultivations may be appropriate.

\section{Summary}

As interest in resource conservation increases, reducing tillage to keep crop residue on top of the soil will become more common. The ever-growing arsenal of herbicides can generally provide good weed control for nearly any tillage system. The key to success is to plan carefully in advance and select treatments that are likely to provide good control of weeds and result in optimum yields.

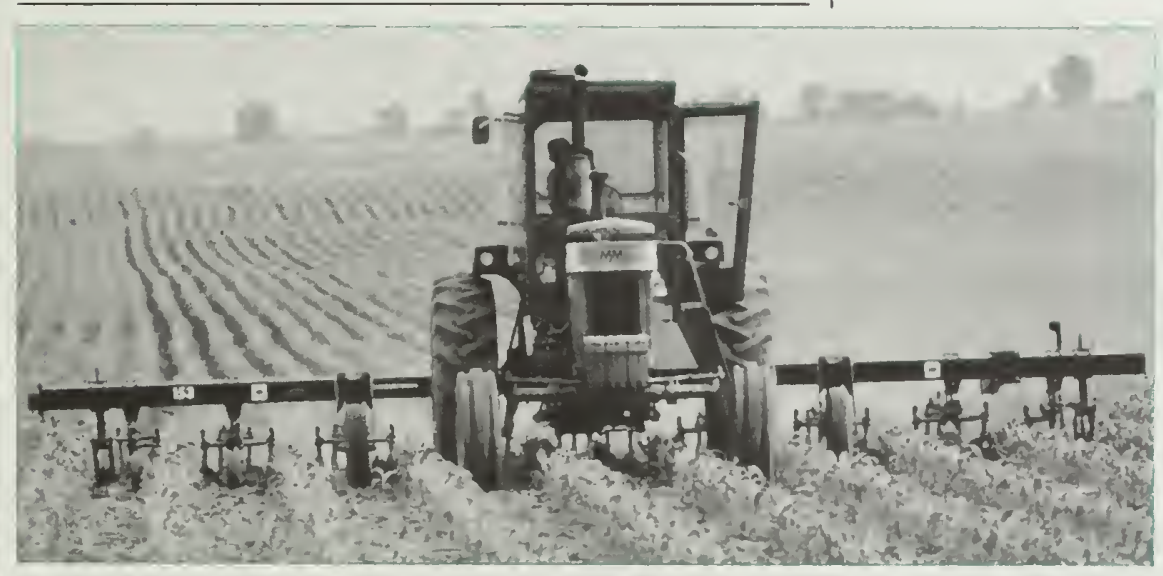

On soils in relatively good tith. some research suggests little or no advantage for cultivation if the herbicide treatment is giving adequate weed control. However if weeds are present and the soil is somewhat crusted, there may be an advantage to cultivation. 


\section{Summary of Weed Control Suggestions for Lo-Till and No-Till}

\section{Lo-Till or No-Till Corn in Soybean Stubble}

Make early preplant applications. If weeds have not emerged, normal herbicide rates may be adequate. If weeds have emerged and are small, triazines may give adequate burndown as well as residual control. If annual grass weeds are over $11 / 2$ inches or annual broadleaf weeds are over 4 inches, consider additional burndown from modest rates of Roundup or Gramoxone. Herbicides such as Dual or Lasso can enhance control of grass weeds. Consider postemergence treatments and cultivation as needed.

\section{Continuous No-Till Corn}

Consider early preplant with surface-applied herbicides or early planting with preemergence treatments. Lasso, Dual, or simazine applied preemergence can help control fall panicum; consider Bladex or Accent for early postemergence control and an approved dinitroaniline or acetanilide midseason to extend control. Roundup, 2,4-D, and Banvel can help if perennial weeds increase.

\section{Soybeans Lo-Till or No-Till After Corn}

Roundup, Gramoxone, or a grass killer such as Poast used within label guidelines can be used for burndown. Herbicides such as Preview or Canopy can give burndown as well as residual control. Consider additional preemergence strength for grass control. There is a wide array of options for postemergence control of both broadleaf and grass weeds.

\section{No-Till Corn in Legume Sod}

The triazines may give adequate control of shallow-rooted clovers and provide residual activity. If control of the clover is marginal in a dry season, a postemergence application of Banvel or 2,4-D can help. For deep-rooted alfalfa, Banvel and 2,4-D can be effective; add a preemergence treatment for residual control of annual weeds.

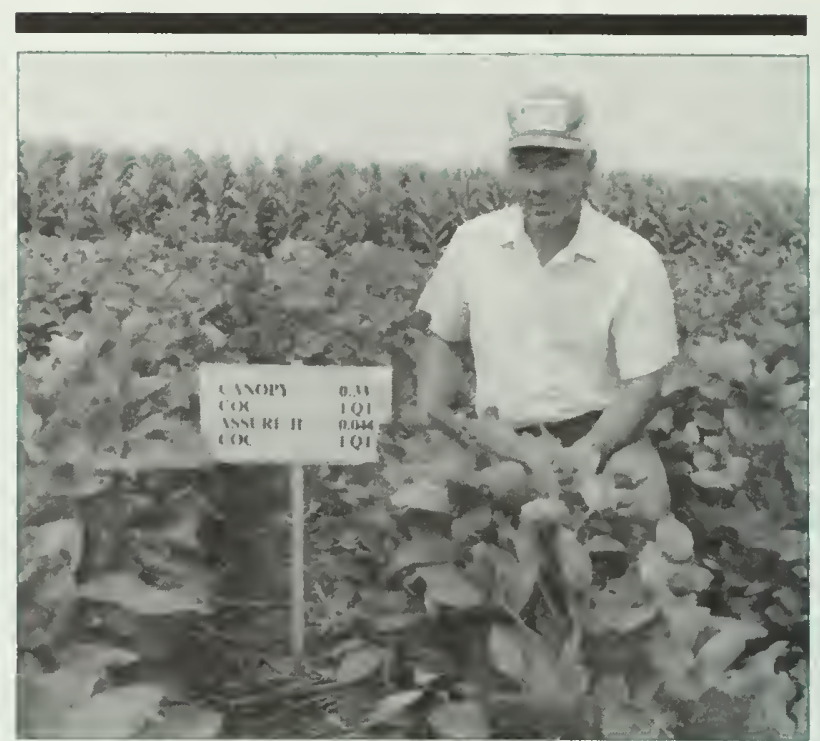

Modern herbicides have helped to make lo-till and no-till systems more feasible.

\section{No-Till Corn in Grass Sod}

Gramoxone plus atrazine has been effective for some grasses, such as tall fescue. Atrazine alone can control bluegrass. If you are using Roundup, plan on fall rather than spring treatments for better control. If feasible, tillage may be more effective and less expensive than some herbicide treatments. Consider legumes without grasses for lower cost control.

\section{No-Till Soybeans in Legume Sod}

Plan ahead for fall treatment with 2,4-D or Banvel used within label guidelines. Do not apply Banvel in the spring before planting soybeans. Some labels have suggested spring use of 2,4-D for a specified period prior to planting soybeans. Roundup is more effective on clover than on alfalfa, and fall treatment is generally more effective than spring treatment. Because postemergence treatments for killing clover or alfalfa in soybeans have not been developed, do not plant soybeans in clover or alfalfa without killing them first.

\section{No-Till Soybeans in Grass Sod}

Roundup, preferably applied in the fall, can provide control of perennial grass if used at relatively high rates. Paraquat plus a herbicidecontaining metribuzin may give fair control. 


\section{Corn in Small-Grain Cover Crop}

Although early application of atrazine alone may sometimes be adequate, modest rates of Roundup or Gramoxone can significantly improve control. Atrazine is more effective for control of small grain than Bladex. Although wheat can be controlled fairly well for either corn or soybeans, rye has been easier to control with some treatments for corn than with herbicides for soybeans. This suggests that corn may be a better choice than soybeans when there is a rye cover crop.

\section{Soybeans in Small-Grain Cover Crop}

Modest rates of Gramoxone or Roundup can be effective for controlling wheat or rye. Fusilade and Assure have been effective on wheat. Wheat is easier to kill than rye. Where spring oats are used on set-aside and allowed to reseed in the summer, the oats will die during the winter. Soybeans can be planted in the oat mulch if herbicide treatments are used.

\section{Double-Crop Soybeans After Wheat}

Gramoxone or Roundup may be used as a burndown treatment supplemented by a preemergence herbicide for residual control. Consider postemergence grass killers for volunteer wheat and some other grass problems. Several postemergence herbicides are available for control of broadleaf weeds. Some preemergence herbicides may also provide burndown.

\section{Ridge-Till}

With the cultural practices commonly used for ridge-till, a burndown will usually not be needed. Emphasis can be placed on preemergence surface applications and postemergence treatments complemented with cultivation. Band applications may be adequate.

\section{Compliance with Label Guidelines}

Some treatments indicated in this publication have been included in research trials but may not yet appear on herbicide labels. When selecting treatments, be certain that they are in accordance with most recent product labels.

Although 2,4-D has been listed on some labels of other herbicides, a residue tolerance for 2,4-D in soybeans has not been established. Thus the legality of using 2,4-D in the spring ahead of soybeans has been questionable.

The herbicide 2,4-DB does have some labeling for use prior to planting soybeans as well as later.

For herbicides such as Preview and Canopy, caution should be taken not to use on soils with $\mathrm{pH}$ in excess of label guidelines. 
Note: The information in this circular is provided for educational purposes only. Trade names have been used for clarity, but reference to trade names does not imply endorsement by the University of Illinois; discrimination is not intended against any product.

Credits: Appreciation is expressed to the individuals who contributed in many ways to make this publication possible. They provided ideas and encouragement, contributed greatly to field research, assisted with preparation of the manuscript, and provided illustrations. Included are colleagues, students, area agronomists, farm foremen, area IPM specialists, area conservation specialists, administrators, SCS personnel, agricultural communications staff, editorial staff, county Extension advisers, industry representatives, and farmers. 




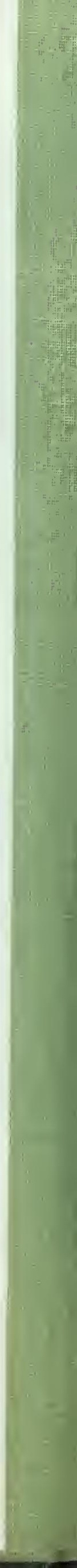



